\title{
Pendampingan Perencanaan Bangunan Gedung Masjid Al-Awwabin Kelurahan Karang Balik Kota Tarakan
}

\section{Edy Utomo ${ }^{*}$, Zulfikhar Ade Mahendra', dan Giar Tri Haryanti'}

${ }^{1}$ Jurusan Teknik Sipil, Universitas Borneo Tarakan

\section{ARTICLE INFO}

\section{Riwayat Artikel:}

Draft diterima: 12 November 2021

Revisi diterima: 06 Desember 2021

Diterima: 26 Desember 2021

Tersedia Online: 27 Desember 2021

Corresponding author:

edyutomog9@gmail.com

\section{Citation:}

Utomo. E, Mahendra. Z. A, Haryanti G. T. 2021. Pendampingan Perencanaan Bangunan Gedung Masjid Al-Awwabin Kelurahan Karang Balik Kota Tarakan. ICOMES: Indonesian Journal of Community Empowerment and Service. 1(1), pp: 10-20

\begin{abstract}
ABSTRAK
Masjid Al-Awwabin merupakan masjid yang dibangun pada tahun 1967. Saat ini kondisi bangunan sudah tidak mampu untuk menampung jama'ah. Berdasarkan hal tersebut pengurus masjid berinisiatif untuk membangun masjid yang baru dengan kapasitas yang lebih memadai. Namun, pengurus masjid mengalami beberapa kendala dalam proses perencanaan masjid, diantaranya adalah 1. Kompleksitas permasalahan topografi lahan, 2. Bentuk desain arsitektur, struktur, dan penyusunan rencana anggaran yang diperlukan, 3. Tidak adanya sumber daya manusia yang memiliki kompetensi memadai dalam perencanaan bangunan. Berdasarkan hal tersebut, tim PKM dari Jurusan Teknik Sipil Universitas Borneo Tarakan berusaha untuk memberikan konstribusi keilmuan dalam perencanaan bangunan masjid tersebut, yang bertujuan untuk menghasilkan desain masjid dengan kapasitas memadai serta memiliki nilai arsitektur dan kekuatan struktur sesuai dengan standarisasi yang berlaku. Metode yang dilakukan diawali dengan melakukan pemetaan lahan, penyelidikan tanah (CPT), membuat desain pendahuluan arsitektur, menganalisa struktur bangunan, membuat gambar detail konstruksi bangunan, dan yang terakhir menghitung nilai rencana anggaran biaya yang diperlukan. Hasil dari kegiatan ini adalah memberikan alternatif desain dengan kapasitas daya tampung jama'ah sebanyak 659 orang, lebih besar dibandingkan dengan daya tampung masjid saat ini. Desain masjid baru yang dihasilkan terdiri dari 3 lantai bangunan, dimana lantai 1 difungsikan sebagai area parkir kendaraan dan sekretariat masjid, lantai ke-2 dan ke3 difungsikan sebagai ruang ibadah utama. Konstruksi masjid menggunakan material beton bertulang yang diperkuat dengan fondasi dalam Strouss Pile pada kedalaman 13,00 Meter. Nilai rencana anggaran biaya yang telah diestimasi adalah sebesar Rp. 10.735.848.000,- berdasarkan pada basic price upah pekerjaan dan material di wilayah Kota Tarakan. Seluruh dokumen desain yang terdiri dari Gambar rencana, Desain struktur, dan DED diserahkan kepada pengurus masjid yang selanjutnya akan berfungsi untuk pengurusan izin mendirikan bangunan serta acuan dalam pelaksanaan pembangunan masjid.
\end{abstract}

Kata kunci: Desain Masjid ; Pengabdian Masyarakat ; Stuktur Bangunan ; Teknik Sipil. 


\begin{abstract}
new mosque consists of 3 floors of the building, where the $1^{\text {st }}$ floor serves as a vehicle parking area and secretariat office, the $2^{\text {nd }}$ and $3^{\text {rd }}$ floors function as the main worship space. The construction of the mosque uses reinforced concrete material with a deep foundation that is Strouss Pile at a depth of 13,00 meters. The estimated value of the cost budget plan is Rp. 10.735.848.000,- based on the basic price of employment and material wages in the Tarakan City area. All design documents consisting of detail drawings, structure design, and DED are submitted to the mosque administrator, which will further serve for the management of building permits as well as references in the implementation of mosque construction.
\end{abstract}

Keywords : Design of the mosque; Community service; Structure of the building; Civil engineering.

\section{PENDAHULUAN Latar Belakang}

Masjid Al-Awwabin yang beralamat di Jl. Adityawarman RT.09 Kelurahan Karang Balik Kecamatan Tarakan Barat Kota Tarakan Provinsi Kalimantan Utara, merupakan masjid dalam kategori masjid umum. Masjid ini dibangun pada tahun 1967 dengan luas tanah dan luas bangunan $300 \mathrm{M}^{2}$ (DKM, 2021). Masjid ini dibangun pada letak yang strategis pada jalan pengubung antara 2 kecamatan (Tarakan Barat Tarakan Tengah), menjadikan masjid ini sangat sering disinggahi oleh masyarakat yang melintas untuk melaksanakan ibadah Sholat Rawatib, pada waktu Maghrib, Dzuhur, dan Ashar. Letak masjid saat ini ditunjukkan pada Gambar 1 sebagai berikut:

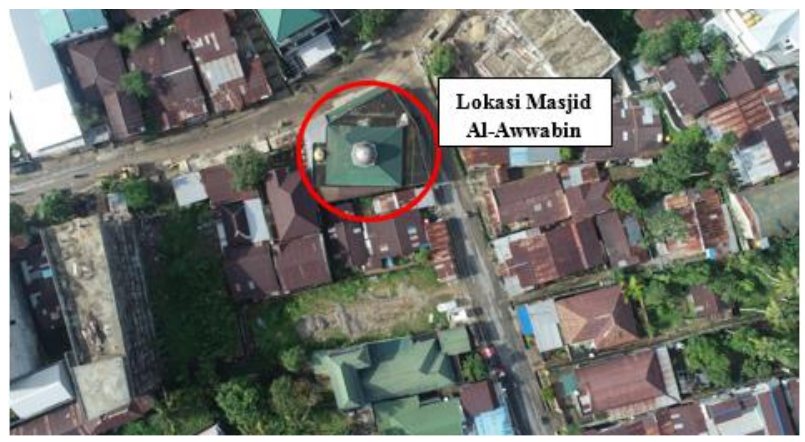

Gambar 1. Foto udara lokasi masjid Al-Awwabin

Kapasitas daya tampung masjid saat ini mengalami peningkatan, dalam arti lain menunjukkan bahwa luas area masjid untuk pelaksanaan sholat tidak lagi mencukupi, terlebih pada pelaksanaan ibadah di hari besar umat Islam, seperti : Idul Fitri, Idul Adha, Sholat Jum'at, dan Sholat Tarawih di bulan suci ramadhan.

Selain itu, penataan ruang bangunan masjid yang kurang baik serta tidak adanya fasilitas penunjang seperti kurangnya ketersediaan Toilet, Kamar mandi, Tempat wudhu jamaah wanita, dan Tempat parkir kendaraan, menyebabkan masjid ini memiliki banyak kekurangan fasilitas untuk dapat dimanfaatkan oleh masyarakat.

Diperkirakan peningkatan kebutuhan kapasitas daya tampung masjid ini juga dipengaruhi oleh perubahan penduduk di daerah Kecamatan Tarakan Barat. Pada tahun 2020 jumlah penduduk muslim tercatat sebesar 67.680 Jiwa (BPS Kota Tarakan, 2021), jumlah tersebut hampir mendekati jumlah penduduk Kecamatan Tarakan Barat pada tahun 2010 yaitu sebesar 68.240 Jiwa (BPS Kota Tarakan, 2010). Pada tahun 2019 tercatat jumlah penduduk yang beragama Islam di Kelurahan Karang Balik sebesar 6.459 Jiwa (BPS Kota Tarakan, 2019), jika diasumsikan 10\% saja penduduk yang beragama Islam melaksanakan ibadah di masjid, maka terdapat 646 penduduk yang menggunakan masjid di wilayah Kelurahan Karang Balik, yang tersebar di 2 masjid, yaitu masjid Al-Awwabin dan masjid Nurul Iman (Komplek LAPAS). Kapasitas kedua masjid ini hampir sama, yaitu \pm 200 Jama'ah yang seharusnya ideal adalah mampu menampung \pm 323 Jama'ah untuk setiap masjid.

Ditinjau dari kondisi lingkungan, letak masjid Al-Awwabin saat ini berada tepat di atas Drainase Primer, dan merupakan daerah cekungan. Sehingga, apabila terjadi curah hujan yang tinggi, maka kerap kali masjid ini megalami musibah banjir, dan tidak dapat dipergunakan.

Selain itu usia bangunan masjid yang mencapai 54 tahun, juga menjadi dasar pertimbangan untuk dilakukannya relokasi bangunan, dengan pertimbangan utama adalah kenyamanan dan keselamatan para jama'ah masjid.

Berdasarkan latar belakang tersebut, jajaran pengurus masjid Al-Awwabin berinisiatif untuk melakukan relokasi dan pembangunan baru masjid Al-Awwabin. Langkah pertama yang dilakukan adalah membentuk Panitia Pembangunan Masjid yang mendapatkan pendampingan 
dari Pemerintah Kota Tarakan, melalui Kelurahan Karang Balik, yang terlegalisasi dalam Surat Keputusan Lurah Karang Balik Kecamatan Tarakan Barat Nomor 14 Tahun 2020.

Saat ini pengurus masjid mendapatkan bantuan tanah wakaf dari Pemerintah Kota Tarakan, dengan lokasi tanah wakaf berada kurang lebih 100 meter ke arah selatan dari letak masjid saat ini, dengan luas lahan sebesar $609 \mathrm{M}^{2}$. Adapun letak tanah yang dimaksud ditunjukkan pada Gambar 2. Bentuk tanah yang tidak simetris, terlebih lagi arah kiblat yang tidak searah dengan lebar maupun panjang tanah, memberikan kesulitan dan tantangan tersendiri bagi Panitia Pelaksana Pembangunan. Oleh sebab itu, diperlukannya pertimbangan dan alternatif desain yang diberikan oleh perancang bangunan sipil untuk menyesuaikan desain dengan kondisi tanah yang ada.

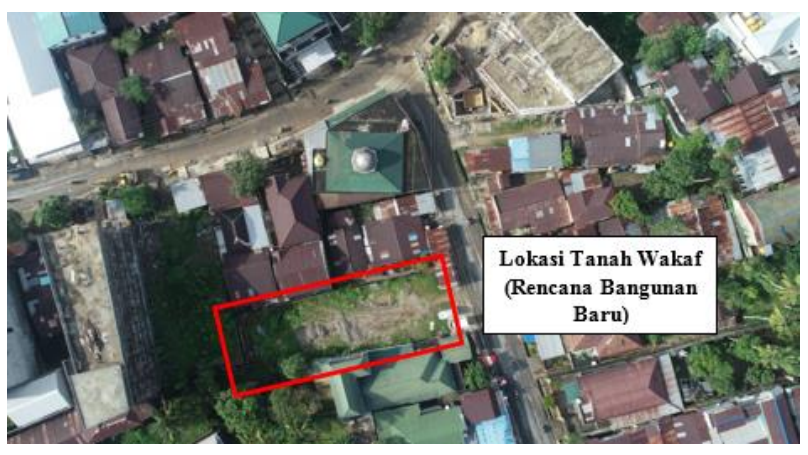

Gambar 2. Lokasi tanah wakaf

Selain permasalahan teknis dan lingkungan yang telah diuraikan, terdapat aturan birokrasi yang harus dipenuhi oleh Panitia Pembangunan, yaitu untuk dapat mengikuti Peraturan Pemerintah Republik Indonesia Nomor 16 Tahun 2021 Tentang Bangunan Gedung. Peraturan tersebut menitikberatkan suatu pembangunan gedung lebih ditinjau terhadap fungsinya, bukan pada izin mendirikan bangunannya. Adapun beberapa hal pokok terkait dengan teknis perencanaan yang perlu diperhatikan berdasarkan PP No.16 Tahun 2021 tersebut adalah sebagai berikut:

a. Ketentuan tata bangunan arsitektur yang dimaksudkan gedung yang direncanakan sesuai dengan fungsinya, seimbang, serasi, dan selaras dengan lingkungannya.

b. Ketentuan intensitas bangunan yang dimaksudkan adalah kepadatan, ketinggian, serta jarak bebas bangunan gedung.

c. Ketentuan keandalan bangunan yang dimaksudkan untuk ketahanan gedung terhadap beban muatan, bahaya kebakaran, dan bahaya lainnya. d. Ketentuan bangunan harus memenuhi aspek kesehatan bangunan yang dimaksudkan untuk penghawaan, pencahayaan, pengelolaan air, dan pengelolaan sampah.

e. Ketentuan kenyamanan bangunan harus memenuhi kenyamanan ruang gerak, sirkulasi udara dalam ruangan, kenyamanan pandangan, dan kenyamanan dari tingkat getaran.

\section{Permasalahan dan Solusi}

Berdasarkan uraian yang telah dijelaskan pada latar belakang, maka dapat ditarik beberapa poin permasalahan yang menjadi dasar akan pentingnya kegiatan pendampingan pada proses perencanaan bangunan masjid Al-Awwabin ini, yaitu :

a. Kompleksitasnya permasalahan yang muncul dari kondisi topografi daerah lokasi pembangunan baru.

b. Banyaknya ketentuan dan persyaratan yang harus dipenuhi oleh Panitia Pembangunan Masjid, baik dari Administrasi, Desain Arsitektur, Desain Struktur hingga kebutuhan Rencana Anggaran Biaya.

c. Tidak adanya sumber daya manusia yang memiliki kompetensi dalam perencanaan bangunan gedung di dalam struktur kepanitiaan pembangunan masjid AlAwwabin.

Berdasarkan 3 permasalahan tersebut, maka solusi yang ditawarkan oleh tim PKM adalah diperlukannya pendampingan perencananaan bangunan tersebut, dengan melibatkan tenaga profesional dan independen. Adapun beberapa solusi teknis yang diberikan yaitu sebagai berikut:

a. Melakukan pengukuran yang akurat baik dengan metode manual, maupun dengan bantuan peralatan modern, yang bertujuan mendapatkan data pemetaan topografi dan pohotogametri yang sesuai dengan kondisi lapangan.

b. Memberikan alternatif desain arsitektur yang sesuai dengan permintaan Panitia Pembangunan, yang selanjutnya diteruskan pada desain struktur bangunan, dan perhitungan RAB perencanaan.

\section{METODE PELAKSANAAN}

Metode pelaksanaan PKM ini dilakukan dengan beberapa tahapan yang harus dilakukan secara berurutan, yang akan dijelaskan secara detail pada sub bab berikut.

\section{Pengukuran Lahan}

Pengukuran lahan dilakukan bertujuan untuk mendapatkan data dimensi dan perbedaan elevasi dari lahan yang tersedia 
untuk pembangunan. Pelaksanaan pengukuran dilakukan dengan metode pengukuran langsung dilapangan menggunakan alat ukur total station yang dikombinasikan dengan pengambilan citra langsung menggunakan drone.

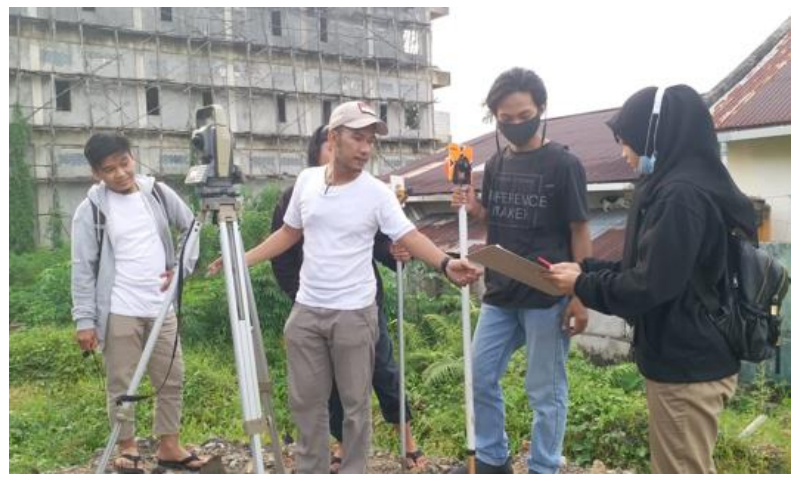

Gambar 3. Kegiatan pengukuran lahan

Berdasarkan pengukuran yang dilakukan mendapatkan hasil dimensi batasan lahan, yang ditunjukkan pada Tabel 1 berikut:

Tabel 1. Hasil pengkuran lahan

\begin{tabular}{lll}
\hline No & Batas Iahan / sisi lahan & Panjang / Luas \\
\hline 1 & Batas utara & 46,79 Meter \\
2 & Batas selatan & 48,67 Meter \\
3 & Batas barat & $10,22 \mathrm{Meter}$ \\
4 & Batas timur & $14,59 \mathrm{Meter}$ \\
5 & Luas lahan & $595,798 \mathrm{M}^{2}$ \\
\hline
\end{tabular}

Dengan gambaran hasil pengukuran dan penentuan letak bangunan terhadap arah kiblat ditunjukkan pada Gambar 4 berikut ini.

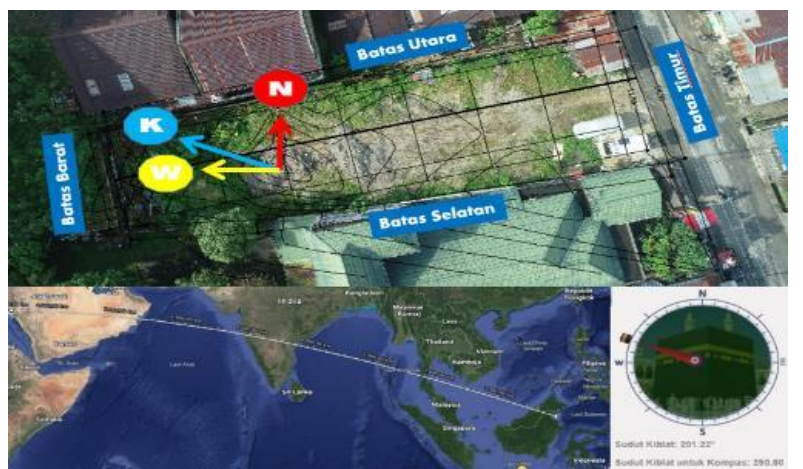

Gambar 4. Skema hasil pengukuran dan penentuan letak bangunan pada arah kiblat.
Berdasarkan pengukuran dan analisis hasil pengukuran didapatkan beberapa permasalahan yang perlu untuk didiskusikan dengan Panita Pembangunan dan Takmir masjid, diantaranya adalah sebagai berikut:

a. Jika bangunan mengikuti kiblat, maka luasan bangunan akan kecil dan tidak dapat memenuhi tujuan utama perencanaan, yaitu pemenuhan peningkatan kapasitas bangunan.

b. Jika bangunan mengikuti lahan, maka posisi shaf sholat akan miring mengikuti arah kiblat, sehingga akan menggangu terhadap estetika lantai.

\section{Pendahuluan Desain Arsitektur}

Setelah pelaksanaan pengukuran dilakukan maka dilanjutkan dengan membuat desain pendahuluan arsitektur bentuk dari masjid sesuai dengan kondisi topografi lahan yang didapatkan. Desain arsitektur dilaksanakan dengan menerapkan metode BIM (Building Information Model) menggunakan bantuan software Sketchup dan Layout. Adapun bentuk model bangunan yang dibuat ditunjukkan pada Gambar 5 sebagai berikut:
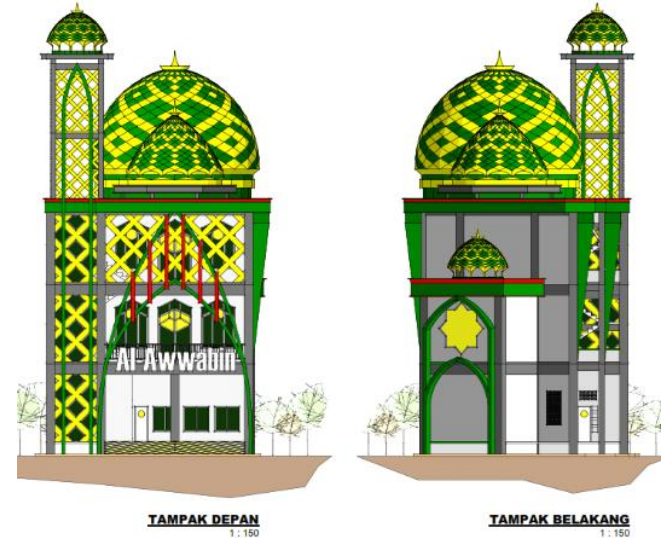

Gambar 5. Desain arsitektur masjid Al-Awwabin

Penerapan metode BIM pada desain arsitektur bertujuan untuk mempermudah dan mempercepat pekerjaan, ketika terjadi perubahan komponen dimensi dari konstruksi bangunan berdasarkan hasil pemodelan struktur yang akan dilakukan pada tahap selanjutnya.

\section{Pemaparan Konsep Desain Arsitektur}

Setelah konsep desain arsitektur dibuat, maka dilanjutkan pada pemaparan hasil kepada pengurus masjid dan panitia pembangunan, dengan tujuan untuk mendapatkan masukan, serta kesepakatan dari konsep yang diharapkan. Proses pemaparan ini dilaksanakan di Kantor Kelurahan Karang Balik, yang juga disaksikan langsung oleh Lurah Karang Balik. Pada proses pemaparan, permasalahan arah 
bangunan dibahas, dan menhasilkan keputusan mufakat, yaitu pemilihan opsi (b) yaitu : Bangunan dibuat mengikuti bentuk lahan, sehingga estetika lantai akan dibuat miring mengikuti arah kiblat. Dengan demikian kapasitas jama'ah akan dihitung berdasarkan kondisi tersebut.

Selain hal tersebut, terdapat juga masukan dari takmir masjid kepada tim PKM untuk dapat memberikan makna dari setiap bentuk yang dibuat pada desain arsitektur.

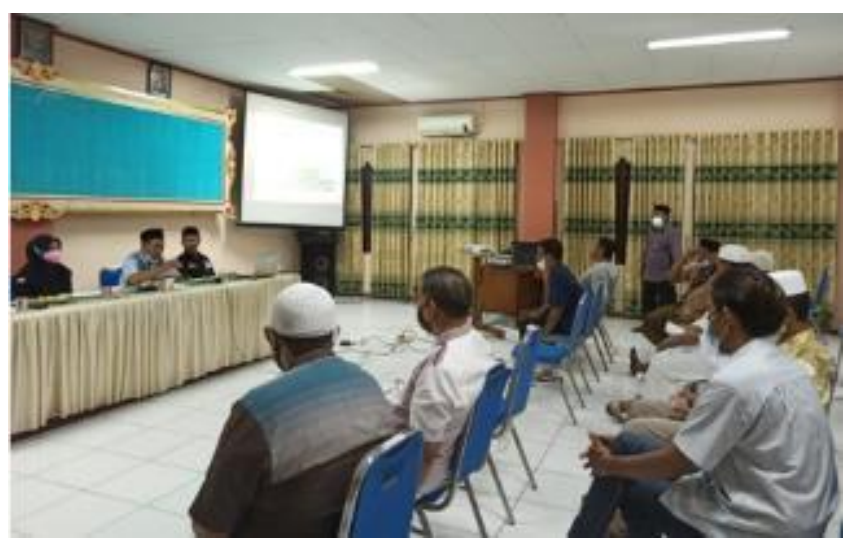

Gambar 6. Proses pemaparan konsep desain

\section{Desain Struktur}

Tahap selanjutnya adalah melakukan desain struktur dari konstruksi bangunan masjid. Desain dilakukan secara otomatis dengan bantuan software FEA untuk dapat mempersingkat waktu pekerjaan. Adapun beberapa standarisasi yang dipergunakan dalam tahap ini adalah sebagai berikut:

a. SNI 1727:2020 (Beban desain minimum dan kriteria terkait untuk banguan dan struktur lain)

b. SNI 1726:2019 (Tata cara perencanaan ketahanan gempa untuk struktur bangunan gedung dan nongedung)

c. SNI 2847:2019 (Persyaratan beton struktural untuk bangunan gedung dan penjelasan)

d. SKBI-1.3.53.1987 (Pedoman perencanaan pembebanan untuk rumah dan gedung)

e. ACI 318-14 (American Concrete Institute)

Seluruh komponen perkiraan dimensi dimodelkan dengan menggunakan bantuan software, termasuk dengan spesifikasi material yang digunakan di dalamnya menyesuaikan dengan kondisi material yang pada umumnya digunakan di sekitar Kota Tarakan. Adapun beberapa spesifikasi material yang digunakan adalah sebagai berikut: a. Mutu beton, $\mathrm{K}-275$ atau setara dengan $\mathrm{f}^{\prime} \mathrm{c}=21,85 \mathrm{Mpa}$, dengan nilai modulus elastisitas sebesar 21.971,47 Mpa.

b. Mutu baja tulangan beton baik pada bentuk sirip (BJTS) maupun bentuk polos (BJTP) menggunakan mutu yang sama, yaitu $\mathrm{f}_{\mathrm{y}}=280 \mathrm{Mpa}, \mathrm{f}_{\mathrm{u}}=350 \mathrm{Mpa}$, dengan pendekatan modulus elastisitas $200.000 \mathrm{Mpa}$.

Pendekatan dinamis beban gempa dimodelkan dengan metode respons spektrum berdasarkan penentuan terbaru yang dikeluarkan oleh Kementerian Pekerjaan Umum. Pendekatan desain spektra ini dapat diakses melalui laman rsa.ciptakarya.pu.go.id/2021/, dengan memberikan input koordinat lokasi bangunan.

Analisis detail desain yang dilakukan secara otomatis dengan menggunakan bantuan software ini perlu untuk disesuaikan pada beberapa parameternya. Hal ini dilakukan untuk memberikan representasi hasil yang sama dengan standard yang digunakan, karena standard default yang tertera pada software menggunakan standard ACI 318-14. Adapun beberapa parameter yang disesuaikan adalah sebagai berikut:
a. Sismic Design Category
$=\mathrm{D}$
b. Design System Rho
$=1,3$
c. Design System Sds (Sesuai Lokasi)
$=0,55$
d. Phi (Tension Controlled)
$=0,80$
e. Phi (Compression Controlled Tied)
$=0,65$
f. Phi (Compression Controlled Spiral) $=0,70$
g. Phi (Shear and/or Torsion)
$=0,75$
h. Phi (Shear Seismic)
$=0,60$
i. Phi (Joint Shear)
$=0,85$
j. Pattern Live Load Factor
$=0,75$
k. Utilization Factor Limit
$=0,95$

Selain dari pada itu, karena kemungkinan pekerjaan akan dilakukan secara swadaya, untuk menghindari ketidaktercapaian dari asumsi material yang direncanakan atau tidak tercapainya asumsi desain, maka perlu untuk dilakukan beberapa rekayasa sipil pada item komponen balok dan kolom. Rekayasa yang dilakukan adalah dengan mengasumsikan bahwa pada balok dan kolom sebagai penampang retak. Menurut Purwono (2005) yang dikutip oleh Satyarno. I, dkk (2012), perlu untuk mengganti nilai prosentase inersia penampang balok adalah 0,35. Nilai ini merupakan prosentase efektivitas penampang dengan memperhitungkan inersia lentur penampang retak. Pada elemen balok, momen lentur utama adalah memutari sumbu ke-3, sehingga dimodifikasi dari 1 menjadi 0,35. Sedangkan pada komponen kolom nilai prosentase penampang retak dirubah menjadi 0,70 pada sumbu ke-2 dan ke-3, hal ini 
dikarenakan momen lentur terjadi memutari kedua sumbu tersebut.

Pemodelan dianggap kaku pada bagian sub-structure, sehingga menggunakan tumpuan jepit untuk merepresentasikan fondasi yang digunakan. Adapun asumsi fondasi yang digunakan adalah fondasi dalam menggunakan sistem strouss pile.

Selain dari hal tersebut, data pendukung lain yang dibutuhkan dalam desain struktur, terutama pada struktur bawah adalah data tanah. Dalam hal ini data tanah diambil menggunakan pendekatan Cone Penetration Test (CPT). Nilai yang didapatkan dari data ini adalah daya dukung tanah dan kemampuan cengkraman tanah (friction), yang nantinya akan digunakan dalam desain Fondasi dari bangunan.

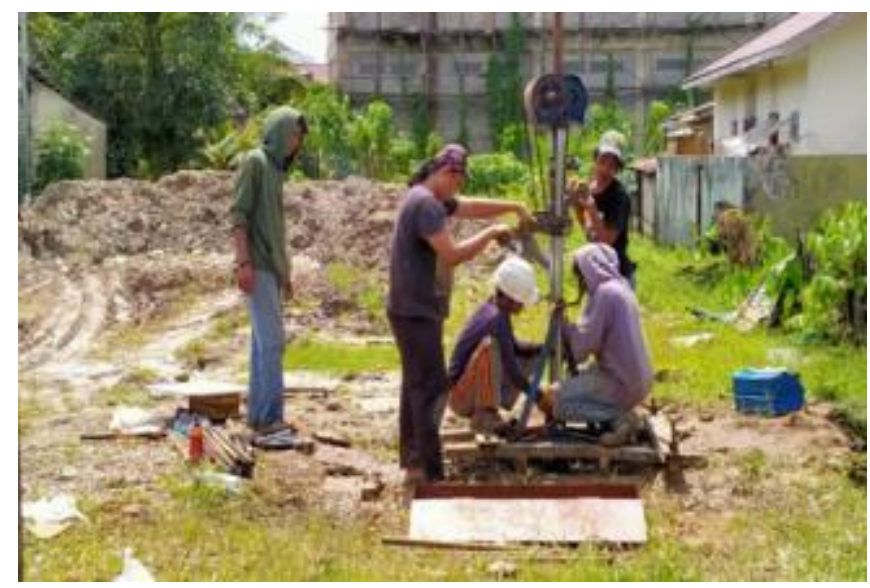

Gambar 7. Proses soil investigation (CPT).

\section{Penggambaran Hasil Desain}

Tahapan selanjutnya setelah hasil desain struktur didapatkan adalah melakukan penggambaran detail kontruksi. Pada proses ini penggambaran dilakukan dengan mengedit model BIM yang telah dibuat sebelumnya, sehingga tidak membutuhkan waktu yang lama untuk melakukan penggambaran. Seluruh hasil desain struktur digambarkan dalam tahap ini, untuk mempermudah dalam perhitungan volume komponen konstruksi yang dibuat.

\section{Estimasi Rencana Anggaran Biaya}

Tahap terakhir dari metode yang dilakukan adalah menghitung rencana anggaran biaya yang diperlukan berdasarkan hasil desain yang telah dibuat. Analisa harga satuan mengacu pada Standard Nasional Indonesia (SNI) dengan basic price yang digunakan disesuaikan dengan harga satuan upah dan material di wilayah Kota Tarakan.

\section{HASIL DAN PEMBAHASAN}

Berdasarkan metode yang telah dilakukan, maka didapatkan beberapa hasil yang perlu untuk dibahas. Dalam hal ini pembahasan dirincikan berdasarkan metode pelaksanaannya masing-masing untuk dapat memberikan gambaran secara terperinci tentang hasil dari PKM ini.

\section{Hasil Pengukuran Lahan Dan Investigasi Tanah}

Selain ukuran lahan yang didapatkan dari pengukuran, didapatkan juga arah bangunan terhadap arah kiblat. Berdasarkan hasil kesepakatan bersama antara pengurus masjid, panitia pembangunan, dan tim PKM bahwa untuk dapat mengoptimalkan kapasitas pengguna, maka bangunan dibuat mengikuti bentuk lahan, sehingga bangunan masjid tidak dibuat simetris seperti yang ditunjukkan pada Gambar 8 berikut:

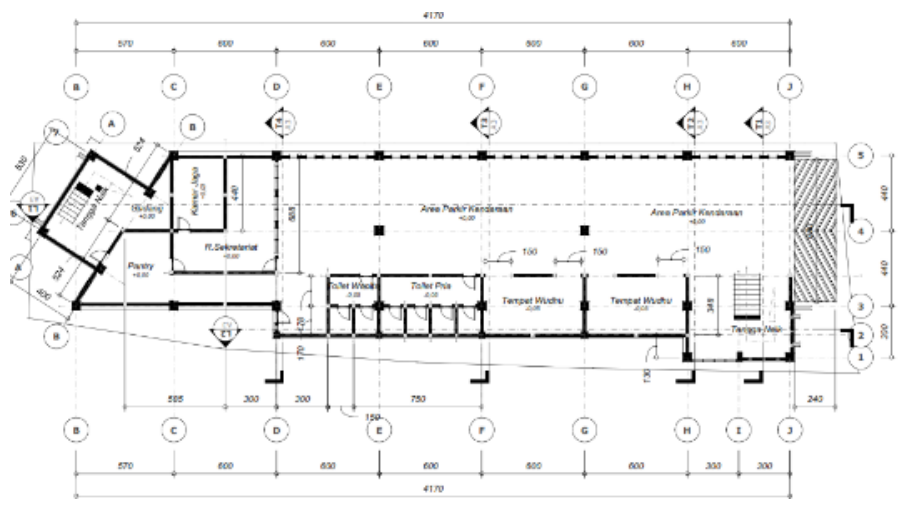

Gambar 8. Bentuk dasar bangunan pada lantai 1

Pada gambar 8 ditunjukkan bentuk dasar bangunan berdasarkan hasil kesepakatan bersama. Pada bagian depan bangunan, yang merupakan posisi letak imaman dibuat miring mengikuti arah kiblat. Hal ini dilakukan untuk menjadi acuan susunan shaf sholat dan acuan pemasangan keramik lantai. Oleh sebab itu bentuk bangunan menjadi tidak simetris. Hal lainnya adalah investigasi data tanah, yang dilakukan dengan menggunakan pendekatan data CPT pada 2 titik sampel. Adapun rekapitlasi hasil yang didapatkan yaitu sebagai berikut:

Tabel 2. Rekapitulasi hasil data CPT

\begin{tabular}{llll}
\hline No & Depth (m) & HK $\left(\mathbf{k g} / \mathbf{c m}^{2}\right)$ & JHL $(\mathbf{k g} / \mathbf{c m})$ \\
\hline 1 & 13,40 & 262,95 & 808,70 \\
2 & 13,00 & 202,27 & 1593,25 \\
\hline
\end{tabular}


Berdasarkan tabel 2, menunjukkan bahwa keadaan tanah keras didapatkan pada kedalaman 13,00 meter dari muka tanah, sehingga desain strouss pile akan dibuat pada kedalaman tersebut dengan menyesuaikan seberapa besar transfer beban total yang akan diberikan oleh bangunan ke tanah.

\section{Hasil Konsep Desain Arsitektur Bangunan}

Berdasarkan pemaparan konsep desain yang dilaksanakan, pengurus masjid dan panitia pembangunan memberikan saran kepada tim PKM untuk dapat memberikan makna dari setiap komponen arsitektur bangunan masjid tersebut. Sehingga tersusunlah beberapa makna, diantaranya sebagai berikut:

a. Filosifi makna pada pemilihan warna bangunan.

- Warna Hijau : melambangkan keistimewaan dalam Islam. Berdasarkan Al-Quran Surah Al-Insan : 21, menjelaskan keadaan penghuni Surga ataupun segala yang ada di sekelilingnya berupa kenikmatan, suasana kesenangan dan ketenangan jiwa.

- Warna Putih : melambangkan kebaikan dan kebersihan, bersumber dari Hadis riwayat Abu Daud No. 4061.

- Warna Kuning : melambangkan daerah letak masjid dibangun, yang diambil dari filosofi ulun pagun dalam bahasa tidung, yang berarti dihormati, dimuliakan, diunggulkan, dan diagungkan.

- Warna Merah : melambangkan warna awan senja pertanda masuknya waktu sholat maghrib di ufuk barat dan sholat subuh di ufuk timur.

- Warna Hitam : melambangkan kedukaan untuk mengingat kematian.

- Warna abu-abu : melambangkan hiruk pikuk sifat Manusia, yang terkadang baik dan terkandang buruk.

Dari rangkaian filosofi warna tersebut, maka disimpulkan bahwa Masjid Al-Awwabin bukan hanya sebagai naungan beribadah, tetapi juga menjadi Building Icon, untuk seluruh umat di wilayah karang balik. Pemilihan warna yang diberikan dapat membangkitkan tergugahnya hati untuk melaksanakan sholat.

b. Filosofi makna pada komponen bentuk bangunan.

- Komponen gerbang masuk depan yang terinspirasi dari bentuk wayang gunungan (Wayang kayon), diciptakan oleh Sunan Kalijaga yang memiliki arti, Asal mula kehidupan adalah kebijaksanaan.
- Jumlah ujung gunungan sebagai ornamen luar sebanyak 30 titik, yang diibaratkan sebagai jumlah juz dalam kitap suci Al-Qur'an.

- Enam pilar berwarna merah di antara gerbang, menunjukkan identitas nama Masjid Al-Awwabin, yang memiliki arti "Seluruh orang yang sering bertobat". Jumlah enam pilar melambangkan 6 rakaat sholat sunnah awwabin yang dikerjakan setelah sholat Maghrib atau setelah sholat Ba'diyah Maghrib.

- Bentuk ketupat segi empat, melambangkan hubungan antara Manusia, Islam, Iman dan Ikhsan.

- Menara melambangkan kelestarian budaya, yang ditinggalkan oleh leluhur.

- Kubah masjid berjumlah 5 kubah, melambangkan waktu sholat wajib.

- Symbol Rub Al-Hizb yang dimodifikasi menjadi AlQuds, merupakan simbol bintang segi delapan, yang memiliki arti kejayaan Islam, yang pernah diperkenalkan oleh kekhalifahan Al-Andalus pada tahun 711 - 1492 Masehi.

- Jumlah lubang di dinding lantai 1 sebanyak 99 lubang, yang menunjukkan Asmaul Husna.

Selain makna dari desain arsitektur tersebut, perubahan kapasitas masjid dan beberapa fungsi ruang juga mengalami perbaikan. Adapun penjabaran fungsi ruang dan luas lantai bangunan sebagai berikut:

a. Lantai 1 difungsikan sebagai tempat parkir kendaraan, tempat wudhu, toilet, kamar marbot, pantry, dan kantor sekretariat pengurus masjid, dengan total luasan lantai $447,7341 \mathrm{M}^{2}$. Area parkir juga dapat dibuat menjadi multi fungsi sebagai tempat sholat khusus untuk hari besar, seperti idul fitri dan idul adha dengan kapasitas daya tampung sebanyak 100 jama'ah.

b. Lantai. 2 difungsikan sebagai ruang sholat utama bagi makmum laki-laki, dengan luas lantai 447,7341 $\mathrm{M}^{2}$ dan kemampuan daya tampung sebanyak 402 jama'ah.

c. Lantai. 3 difungsikan sebagai ruang sholat bagi makmum perempuan, dengan luas lantai 289,1906 $\mathrm{M}^{2}$ dan kemampuan daya tampung sebanyak 257 jama'ah.

Berdasarkan hal tersebut, maka total kapasitas daya tampung masjid meningkat dari kondisi awal hanya mampu menampung 200 jama'ah, dengan desain terbaru menjadi 659 jama'ah pada kondisi normal dan pada pelaksanaan sholat di hari besar umat Islam mampu menampung 759 jama'ah. Hal ini menunjukkan bahwa kondisi permasalahan pertama untuk kapasitas masjid sudah dapat ditangani dengan desain masjid yang terbaru. Selain itu, tidak 
tersedianya lahan parkir pada masjid lama sehingga menimbulkan kemacetan lalu lintas akibat parkir yang tidak beraturan juga teratasi dengan konsep desain yang diberikan, dengan memanfaatkan ruang pada lantai 1 bangunan sebagai tempat parkir kendaraan.

\section{Hasil Desain Struktur}

Berdasarkan hasil analisis desain struktur bangunan, konstruksi bangunan masjid menggunakan material beton bertulang, dengan mutu beton K-275 dan mutu tulangan beton yang digunakan adalah BJTS-280 dan BJTP-280. Adapun rincian dimensi dari setiap komponen strukturnya ditunjukkan pada Tabel 3 berikut ini:

Tabel 3. Rincian dimensi komponen struktur beton

\begin{tabular}{clcc}
\hline No & Komponen & Kode & $\begin{array}{c}\text { Dimensi } \\
\text { b/d } \\
\text { (cm) }\end{array}$ \\
\hline 1 & Sloof & SL.1 & $40 / 75$ \\
2 & Sloof & SL.2 & $30 / 50$ \\
3 & Sloof & SL.3 & $30 / 75$ \\
4 & Balok & B1 & $40 / 75$ \\
5 & Balok & B2 & $30 / 60$ \\
6 & Balok & B3 & $25 / 40$ \\
7 & B.Bordes & BB & $25 / 40$ \\
8 & Ring Balk & RB1 & $30 / 60$ \\
9 & Ring Balk & RB2 & $25 / 40$ \\
10 & Ring Balk & RB3 & $25 / 40$ \\
11 & Pedestail & KPD.1 & $50 / 50$ \\
12 & Pedestail & KPD.2 & $35 / 35$ \\
14 & Kolom & K1 & $50 / 50$ \\
15 & Kolom & K2 & $35 / 35$ \\
16 & Slab & Lantai.1 & $\mathrm{t}=12$ \\
17 & Slab & Lantai.2 & $\mathrm{t}=12$ \\
18 & Slab & Lantai.3 & $\mathrm{t}=12$ \\
19 & Slab & Top Floor & $\mathrm{t}=12$ \\
20 & Fondasi & FP.4 & $170 / 170$ \\
21 & Strouss Pile & SP & $\varnothing 30-$ Depth 13 Meter \\
\hline
\end{tabular}

Desain yang dilakukan menyesuaikan dengan kondisi material bangunan yang umum beredar di Kota Tarakan, terutama pada material baja tulangan beton. Berdasarkan standarisasi SNI 1726:2019 untuk bangunan tahan gempa disyaratkan perlunya penggunaan baja tulangan beton dengan mutu BJTS-420. Namun, dipasaran Kota Tarakan material tersebut sulit untuk didapatkan, hal ini dikarenakan pihak penyedia material hanya menyediakan baja tulangan yang umum dipergunakan oleh masyarakat. Oleh sebab itu, hasil desain penulangan beton memberikan banyaknya jumlah tulangan yang harus dipergunakan, karena didesain dengan menggunakan BJTS-280. Hal ini dipengaruhi perbedaan yang jauh dari nilai kuat leleh baja tulangan, yang seharusnya $420 \mathrm{Mpa}$ dirubah menjadi 280 Mpa. Berdasarkan hal tersebut, tim PKM menemukan problematika baru terkait dengan keperluan desain struktur yang umum dilaksanakan sesuai standard, namun kondisi lapangan tidak memungkinkan untuk memenuhi standard tersebut. Oleh sebab itu perlu untuk melakukan edukasi terhadap masyarakat terutama para pekerja bangunan lepas tentang perbedaan mutu baja tulangan tersebut. Adapun rincian kebutuhan tulangan pada setiap komponen beton ditunjukkan pada Tabel 4 berikut ini:

Tabel 4. Rincian penulangan komponen beton

\begin{tabular}{|c|c|c|c|c|}
\hline No & Kode & Tul. Tumpuan & Tul. Lapangan & Tor \\
\hline \multirow{4}{*}{1} & \multirow{4}{*}{ SL.1 } & Top: 4D19/2D13 & Top: 4D19/2D13 & \multirow{4}{*}{$6 \mathrm{D} 16$} \\
\hline & & Bot: 4D19/2D13 & Bot: 4D19/2D13 & \\
\hline & & Shear: & Shear: & \\
\hline & & P10-50 & P10-150 & \\
\hline \multirow{4}{*}{2} & \multirow{4}{*}{ SL.2 } & Top: 4D19 & Top: 3D19 & \multirow{4}{*}{ - } \\
\hline & & Bot: 2D19/2D13 & Bot: 3D19 & \\
\hline & & Shear: & Shear: & \\
\hline & & P10-100 & P10-200 & \\
\hline \multirow{4}{*}{3} & \multirow{4}{*}{ SL.3 } & Top: 4D19 & Top: 4D19 & \multirow{4}{*}{-} \\
\hline & & Bot: 4D19 & Bot: 4D19 & \\
\hline & & Shear: & Shear : & \\
\hline & & P10-55 & P10-100 & \\
\hline \multirow{4}{*}{4} & \multirow{4}{*}{ B1 } & Top: 5D19/11D13 & Top: 5D19 & \multirow{4}{*}{ 8D16 } \\
\hline & & Bot: 5D19 & Bot: 5D19 & \\
\hline & & Shear: & Shear: & \\
\hline & & P10-60 & P10-100 & \\
\hline \multirow{4}{*}{5} & \multirow{4}{*}{ B2 } & Top: 5D19 & Top: 3D19 & \multirow{4}{*}{ - } \\
\hline & & Bot: 3D19 & Bot: 3D19 & \\
\hline & & Shear: & Shear: & \\
\hline & & P10-75 & P10-75 & \\
\hline \multirow{4}{*}{6} & \multirow{4}{*}{ B3 } & Top: 4D19/3D13 & Top: 2D19 & \multirow{4}{*}{ 4D13 } \\
\hline & & Bot: 3D19 & Bot: 2D19 & \\
\hline & & Shear: & Shear: & \\
\hline & & P10-70 & P10-200 & \\
\hline \multirow{4}{*}{7} & \multirow{4}{*}{ BB } & Top: 3D16 & Top: 3D16 & \\
\hline & & Bot: 3D16 & Bot: 3D16 & \\
\hline & & Shear: & Shear: & \\
\hline & & P10-180 & P10-180 & \\
\hline \multirow{4}{*}{8} & \multirow{4}{*}{ RB1 } & Top: 4D19/2D13 & Top: 3D19 & \\
\hline & & Bot: 3D19 & Bot: 3D19 & \\
\hline & & Shear: & Shear: & \\
\hline & & P10-145 & P10-200 & \\
\hline \multirow{4}{*}{9} & \multirow{4}{*}{ RB2 } & Top: 3D16 & Top: 3D16 & \\
\hline & & Bot: 3D16 & Bot: 3D16 & \\
\hline & & Shear: & Shear : & \\
\hline & & P10-180 & P10-180 & \\
\hline \multirow{3}{*}{10} & \multirow{3}{*}{ RB3 } & Top: 3D16/2D13 & Top: 3D16 & \multirow{3}{*}{$6 \mathrm{D} 13$} \\
\hline & & Bot: 3D16 & Bot: 3D16 & \\
\hline & & Shear: & Shear : & \\
\hline
\end{tabular}




\begin{tabular}{|c|c|c|c|c|}
\hline & & P10-180 & P10-200 & \\
\hline 11 & KPD.1 & $\begin{array}{l}\text { Long: 12D19 } \\
\text { Shear: P13-85 }\end{array}$ & $\begin{array}{l}\text { Long: 12D19 } \\
\text { Shear: P13-120 }\end{array}$ & - \\
\hline 12 & KPD.2 & $\begin{array}{l}\text { Long: 8D16 } \\
\text { Shear: P10-50 }\end{array}$ & $\begin{array}{l}\text { Long: 8D16 } \\
\text { Shear: P10-140 }\end{array}$ & - \\
\hline 14 & K1 & $\begin{array}{c}\text { Long: 12D19 } \\
\text { Shear: P13-95 }\end{array}$ & $\begin{array}{c}\text { Long: 12D19 } \\
\text { Shear: P13-100 }\end{array}$ & - \\
\hline 15 & K2 & $\begin{array}{l}\text { Long: 8D16 } \\
\text { Shear: P10-50 }\end{array}$ & $\begin{array}{c}\text { Long: 8D16 } \\
\text { Shear: P10-140 }\end{array}$ & - \\
\hline 16 & Lantai.1 & \multicolumn{2}{|c|}{$\begin{array}{l}\text { Tulangan Arah x P10 - } 150 \\
\text { Tulangan Arah y P10 - } 150\end{array}$} & $\begin{array}{c}2 \\
\text { Lapis }\end{array}$ \\
\hline 17 & Lantai.2 & \multicolumn{2}{|c|}{$\begin{array}{l}\text { Tulangan Arah x P10 - } 150 \\
\text { Tulangan Arah y P10 - } 150\end{array}$} & $\begin{array}{c}2 \\
\text { Lapis }\end{array}$ \\
\hline 18 & Lantai.3 & \multicolumn{2}{|c|}{$\begin{array}{l}\text { Tulangan Arah x P10 - } 150 \\
\text { Tulangan Arah y P10 - } 150\end{array}$} & $\begin{array}{c}2 \\
\text { Lapis }\end{array}$ \\
\hline 19 & $\begin{array}{l}\text { Top } \\
\text { Floor }\end{array}$ & \multicolumn{2}{|c|}{$\begin{array}{l}\text { Tulangan Arah x P10 - } 150 \\
\text { Tulangan Arah y P10 - } 150\end{array}$} & $\begin{array}{c}2 \\
\text { Lapis }\end{array}$ \\
\hline 20 & FP.4 & \multicolumn{2}{|c|}{$\begin{array}{c}\text { Tul. Lentur Arah x D19 - } 150 \\
\text { Tul. Lentur Arah y D19 - } 150 \\
\text { Tul. Susut Arah x P13 - } 180 \\
\text { Tul. Susut Arah y P13 - } 180 \\
\end{array}$} & - \\
\hline 21 & SP & $\begin{array}{l}\text { Long: 8D13 } \\
\text { Spiral P8-150 }\end{array}$ & $\begin{array}{c}\text { Long: 8D13 } \\
\text { Spiral P8-150 }\end{array}$ & - \\
\hline
\end{tabular}

\section{Hasil Estimasi Anggaran Biaya}

Hasil estimasi rancana anggaran biaya yang diperlukan untuk merealisasikan desain yang telah dibuat adalah sebesar Rp. 10.735.848.000,00. Nilai ini merupakan nilai total anggaran yang dihitung berdasarkan analisa harga satuan SNI dengan input basic price berasal dari HSPK (Harga Satuan Pokok Kegiatan) Kota Tarakan tahun 2021, dengan rekapitulasi seperti pada Tabel 5 berikut.

Tabel 5. Rekapitulasi rencana anggaran biaya

\begin{tabular}{clc}
\hline No & \multicolumn{1}{c}{ Item Pekerjaan } & $\begin{array}{c}\text { Jumlah Harga } \\
\text { (Rp) }\end{array}$ \\
\hline I. & Pekerjaan Pendahuluan & \\
& $\begin{array}{l}\text { A. Pekerjaan turap dinding } \\
\text { penahan tanah }\end{array}$ & $36.133 .424,80$ \\
& $\begin{array}{l}\text { B. Pekerjaan drainase sisi } \\
\text { bangunan }\end{array}$ & $15.725 .838,52$ \\
& \\
II. & Pekerjaan Struktur & $2.019 .751 .482,27$ \\
& A. Pek. Struktur Lantai. 1 & $1.313 .208 .889,69$ \\
& B. Pek. Struktur Lantai. 2 & $1.177 .098 .571,53$ \\
\hline & C. Pek. Struktur Lantai. 3 & $956.014 .299,76$ \\
& D. Pek. Struktur Top Floor & \\
III. & Pekerjaan Arsitektur & $552.298 .781,22$ \\
& A. Pek. Arsitektur Lantai. 1 & $762.295 .688,17$ \\
& B. Pek. Arsitektur Lantai. 2 & $617.971 .736,28$
\end{tabular}

Selain nilai total rencana anggaran biaya yang diperlukan tersebut, juga dilakukan analisis perhitungan untuk menentukan nilai anggaran biaya upah pekerjaan. Hal ini dilakukan apabila pihak pengurus masjid dan panitia pembangunan dalam proses pelaksanaan pembangunan nanti akan melibatkan pihak kedua pada sektor jasa tenaga kerja, dengan manjemen material atau bahan bangunan ditangani langsung oleh panitia pembangunan. Adapun nilai upah pekerjaan total termasuk dengan PPN 10\% adalah sebesar Rp. 3.202.529.000,-. Berdasarkan nilai ini panitia pembangunan dapat menentukan harga satuan upah pemborongan pekerjaan, dengan membagi nilai upah kerja total dengan luasan bangunan. Adapun harga pemborongan yang dijadikan batasan maksimum untuk penawaran jasa pekerjaan adalah sebesar Rp. 1.961.800,-/M² luas bangunan.

Skema pendanaan material bangunan juga dapat direalisasikan dengan melibatkan para jama'ah atau warga sekitar lingkungan masjid Al-Awwabin, yaitu dengan penetapan nilai sumbangan wakaf per luasan bangunan. Adapun nilai total kebutuhan material, termasuk pajak adalah sebesar Rp. 8.684.708.000,- dengan acuan nilai ini maka dapat ditetapkan nilai wakaf pembangunan minimum adalah sebesar Rp. 5.320.000,- / $\mathrm{M}^{2}$ luas bagunan. Maka jika ditotal secara keseluruhan, dapat ditetapkan nilai wakaf minimal untuk pengumpulan anggaran pembangunan adalah sebesar Rp. 7.281.800,- / $\mathrm{M}^{2}$ luas bangunan.

\section{Hasil Akhir PKM}

Seluruh rangkaian metode pelaksanaan PKM yang telah dilakukan, selanjutnya dituangkan ke dalam bentuk dokumen tertulis, yang nantinya dapat dipergunakan oleh pengurus masjid dan panitia pembangunan untuk kepengurusan izin dan hal-hal lainnya terkait pelaksanaan pembangunan masjid ini.

Adapun dokumen yang diserahkan kepada pengurus masjid yang diwakili oleh wakil ketua takmir masjid Bapak H. Abdul Manan (tengah pada gambar 9), dan ketua panita pembangunan Bapak Rahmat Kartolo (kiri pada gambar 9) yang diserahkan langsung oleh ketua tim PKM Ir. Edy Utomo, ST., MT. (kanan pada gambar 9) adalah 2 dokumen desain 
struktur bangunan, 2 dokumen gambar detail arsitekturstruktur dalam format A3, dan 2 dokumen detail engineering design yang memuat rencana anggaran biaya total, upah pekerjaan dan kebutuhan material.

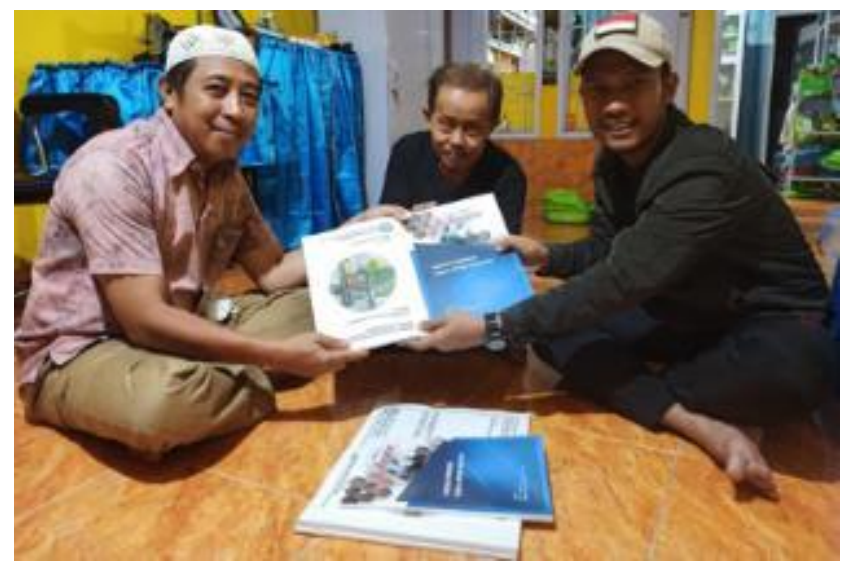

Gambar 9. Penyerahan dokumen hasil desain

Adapun dokumen yang diserahkan kepada pengurus masjid yang diwakili oleh wakil ketua takmir masjid Bapak H. Abdul Manan (tengah pada Gambar 9), dan ketua panita pembangunan Bapak Rahmat Kartolo (kiri pada Gambar 9) yang diserahkan langsung oleh ketua tim PKM Ir. Edy Utomo, ST., MT. (kanan pada Gambar 9) adalah 2 dokumen desain struktur bangunan, 2 dokumen Gambar detail arsitekturstruktur dalam format A3, dan 2 dokumen detail engineering design yang memuat rencana anggaran biaya total, upah pekerjaan dan kebutuhan material.

Dalam proses pelaksanaan PKM ini, tim hanya menghabiskan biaya sebesar Rp. 5.060.500,- yang bersumber dari dana DIPA/PNBP Universitas Borneo Tarakan. Serapan anggaran terbesar adalah $82,64 \%$ yang dipergunakan untuk keperluan teknis seperti pengambilan foto udara dengan rincian sewa peralatan drone, pengukuran lahan dengan rincian sewa peralatan ukur total station TKS-202, pengambilan data CPT dengan rincian pembayaran jasa CPT, dan perbaikan printer untuk mencetak Gambar dalam ukuran A3. Sedangkan 5,61\% anggaran dipergunakan pada bahan habis pakai termasuk kebutuhan saat rapat, dan $11,75 \%$ dipergunakan untuk keperluan ATK dan publikasi ilmiah.

\section{KESIMPULAN}

Berdasarkan rangkaian kegiatan dan metode dalam PKM yang dijalankan ini, maka dapat ditarik kesimpulan bahwa tim PKM telah berhasil untuk berkontribusi langsung kepada masyarakat melalui bidang keahlian teknik sipil yang dimiliki. Kegiatan PKM telah memberikan jawaban dari setiap permasalahan yang dihadapi oleh masyarakat yaitu pengurus masjid dan panitia pembangunan, dalam bentuk dokumen konsepsi, ide, dan analisis ilmiah yang tertuang dalam dokumen perencanaan.

\section{UCAPAN TERIMA KASIH}

Terlaksananya PKM ini tentu tidaklah lepas dari bantuan dan dukungan dari beberapa pihak. Oleh sebab itu, tim PKM memanfaatkan kesempatan dalam tulisan ilmiah ini untuk mengucapkan terima kasih kepada pihak-pihak yang telah berkontribusi dan mendukung kegiatan PKM ini, antara lain kepada:

a. Lembaga Penelitian dan Pengabdian Masyarakat (LPPM) Universitas Borneo Tarakan, yang telah memberikan kesempatan kepada tim PKM untuk ikut ambil bagian dalam program kemitraan bagi masyarakat.

b. Ketua Jurusan Teknik Sipil Fakultas Teknik Universitas Borneo Tarakan, yang telah memberikan izin kepada Tim PKM untuk dapat melaksanakan program kemitraan bagi masyarakat.

c. Kelurahan Karang Balik, Kecamatan Tarakan Barat, Kota Tarakan, yang telah memberikan izin kepada tim untuk malaksanakan PKM di daerahnya.

d. Panitia Pembangunan Masjid Al-Awwabin dan Pengurus Masjid Al-Awwabin yang telah mempercayakan pendampingan perencanaan bangunan masjid kepada Tim PKM.

e. PT. Bumi Kaltara Konsultan yang telah bersedia membantu dalam pengukuran lahan, pemetaan foto udara, dan penyelidikan tanah dengan metode CPT.

f. Mahasiswa/i Jurusan Teknik Sipil Fakultas Teknik Universitas Borneo Tarakan yang telah membantu berkontribusi dalam pelaksanaan PKM.

g. Jajaran syuriah pengurus Ranting Nahdlatul Ulama Kelurahan Karang Balik Kota Tarakan, yang telah memberikan masukan folosofi pada desain arsitektur bangunan masjid.

\section{DAFTAR PUSTAKA}

Badan Standarisasi Nasional, (2019), SNI 1726:2019, Tata cara perencanaan ketahanan gempa untuk struktur bangunan gedung dan non gedung. Jakarta.

Badan Standarisasi Nasional, (2019), SNI 2847:2019, Persyaratan beton struktural untuk bangunan gedung dan penjelasan, Jakarta.

Badan Standarisasi Nasional, (2020), SNI 1727:2020, Beban desain minimum dan kriteria untuk bangunan dan struktur lain, Jakarta. 
BPS Kota Tarakan, (2010). Kota Tarakan Dalam Angka 2010, Tarakan, 6473.1001.copyright BPS Kota Tarakan.

BPS Kota Tarakan, (2019). Kecamatan Tarakan Barat Dalam Angka 2019, Tarakan, ISBN : 978-602-70898-6-0. Copyright BPS Kota Tarakan.

BPS Kota Tarakan, (2021), Kota Tarakan Dalam Angka 2021, Tarakan, ISSN : 1907-2139.Copyright BPS Kota Tarakan.

Departemen Pekerjaan Umum, (1987), Pedoman perencanaan pembebanan untuk rumah dan gedung, SKBI-1.3.53.1987, UDC : 624.042. Jakarta.

Dewan Kemakmuran Masjid, (2021), Masjid Al-Awwabin Jl. Adityawarman RT.09 Kelurahan Karang Balik, DKM.or.id/dkm/13054/masjid-al-awwabin-tarakanbarat-kota-tarakan.html. (diakses tanggal 28 Februari 2021).

Peraturan Pemerintah Republik Indonesia No.16, (2021), Peraturan Pelaksanaan Undang-Undang Nomor 28 Tahun 2002, Tentang Bangunan Gedung, Jakarta.

Satyarno.I, Nawangalam.P, Pratomo.RI, (2012),Belajar SAP200 Analisis Gempa, Zamil Publishing, Yogyakarta.

\section{LAMPIRAN}

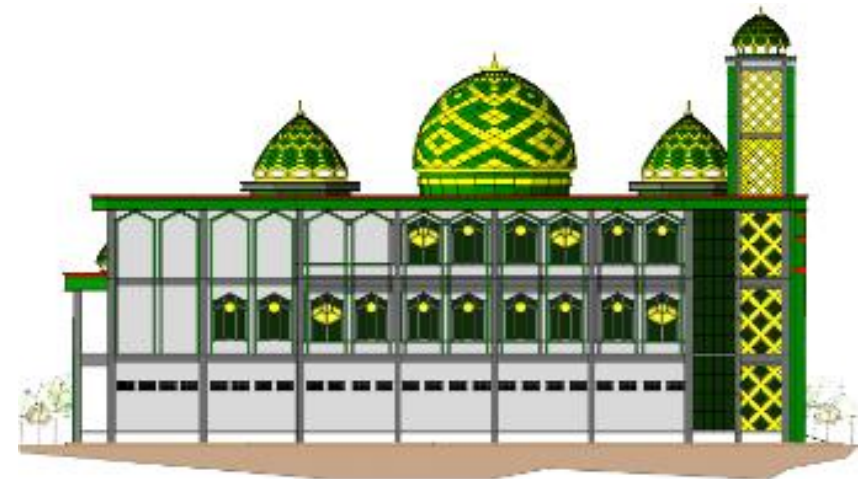

\section{Gambar tampak samping desain masjid}

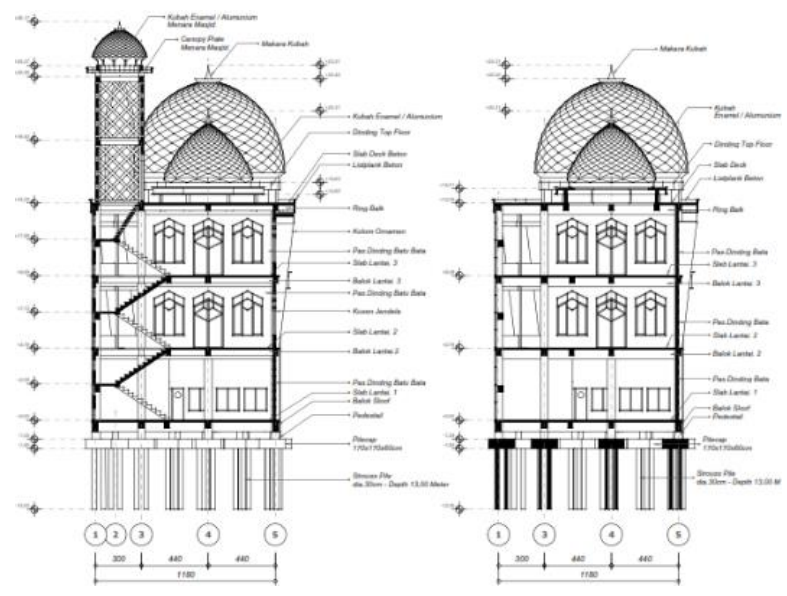

Gambar section melintang bangunan masjid

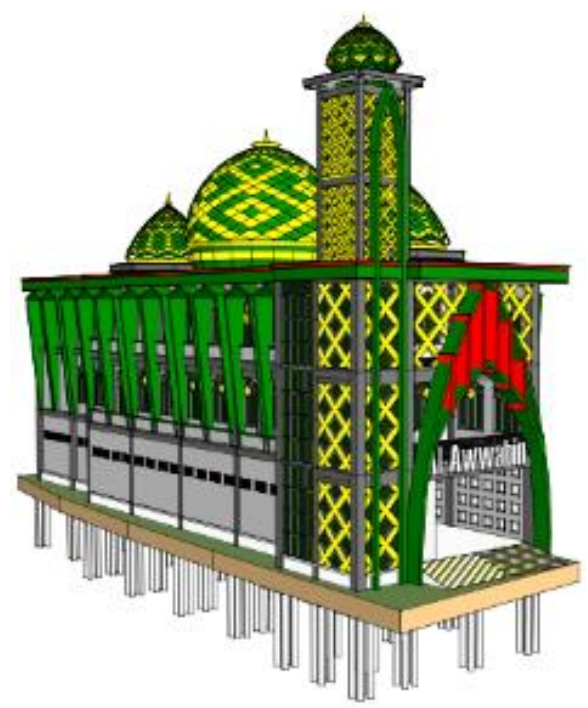

Gambar tampak 3 dimensi desain masjid

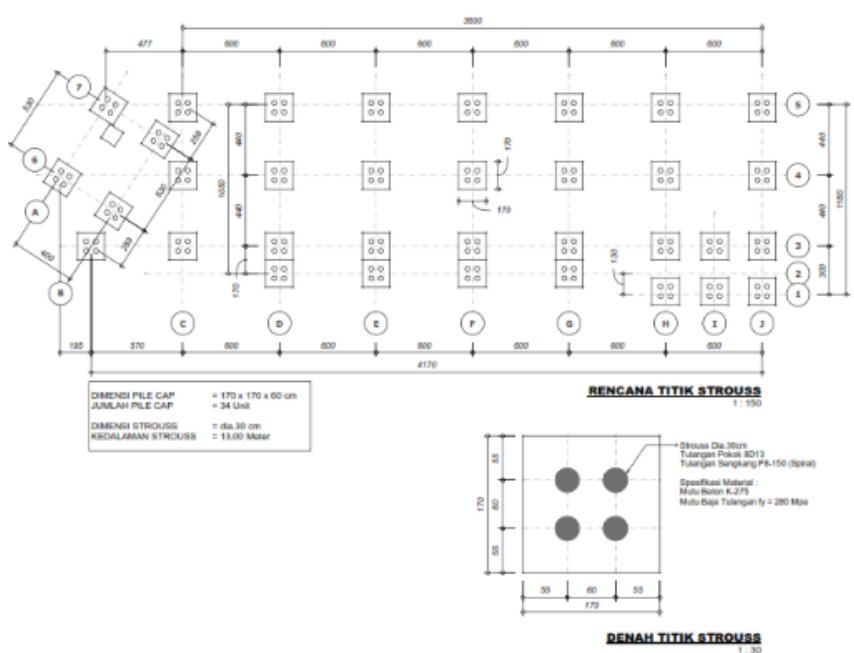

Gambar rencana titik pancang dan fondasi

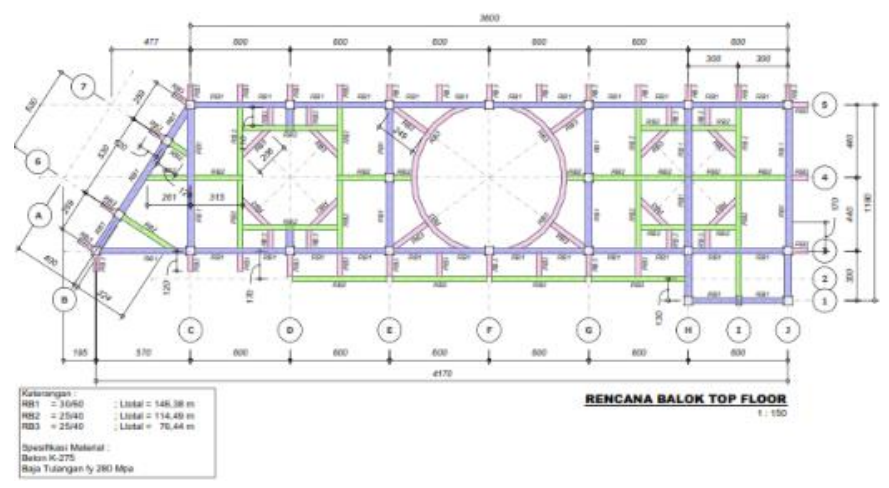

Gambar rencana sistem balok top floor 